\title{
Effect of daylength on voluntary intake, extent of digestion and chewing behaviour in housed sheep
}

\author{
AG Deswysen 1, L Desprès 2, F Beckers 1, V Fischer 1, EH Amouche 1 \\ 1Faculté des Sciences Agronomiques, Unités de Génétique et de Biométrie, Université Catholique de Louvain, \\ Place Croix du Sud 2 (Boite 14), 1348, Louvain-la-Neuve, Belgique ; 2INRA, Laboratoire Sous-Nutrition \\ des Ruminants, 63122 St-Genès-Champanelle, France
}

Most feed evaluation studies of conserved forages are performed indoors with "standard" sheep and cattle. Ingestibility, digestibility and chewing behaviour patterns associated with a forage are measured at a given time of the year giving one observed value. However, influence of photoperiod on voluntary intake was clearly shown in ewes (Bocquier, 1985, Thèse, INA Paris, $105 p$ ) and adult wethers (Michalet-Doreau and Gatel, 1988, Ann Zootech, 37, 151-158).

Objective of present study is to evaluate evolution of voluntary intake, extent of digestion and chewing behaviour in sheep housed from october through march under continuous artificial lighting additional to natural daylength.

Three wethers and six ewes, $1 / 2$ lle de France $x$ $1 / 2$ Texel, 6 to 9 months old at beginning of experiment were fed during 6 sequential periods (october through march) chopped hay ( $94.7 \pm$ $0.2 \% \mathrm{OM}, 69.1 \pm 1.0 \% \mathrm{NDF}, 6.7 \pm 0.5 \% \mathrm{CP}$ ) ad libitum and $250 \mathrm{~g} / \mathrm{d}$ concentrate $(92.3 \pm$ $0.3 \%$ OM, $36.5 \pm 1.6 \%$ NDF, $15.5 \pm 1.0 \% \mathrm{CP}$ ). Each experimental period lasted at least $28 \mathrm{~d}$ : minimum $11 \mathrm{~d}$ of "rest" in individual straw bedded floor pens, followed by $7 \mathrm{~d}$ adaptation to digestion crates and wearing of a harness with sponge-filled rubber balloon to record jaw movements ( 3 or 4 last d), and 10 last $d$ of measurements of daily voluntary intake, extent of digestion and concurrently $5 \mathrm{~d}$ of continuous recording of jaw movements. Data were subjected to variance analysis for repeated measurements using a F-test adjusted according the epsilon coefficient of HuynhFeldt (1976, cited in SAS user's guide, 1990, Vol. 2, GLM VARCOMP, Version 6, SAS Institute Inc). Pairwise differences between periods were tested using contrasts.

Voluntary intake decreased from october to January, and increased significantly in February and march. Digestibility of $O M$ and NDF, daily eating and ruminating time were unchanged throughout the 6 months. However, digestibility of $C P$, unitary eating and ruminating time were largest in January. Lowest intake level in January was associated with largest number of daily meals which were of shortest mean duration.

Results are interpreted to suggest that ingestibility (fill units) and associated mastication index for a given forage or diet is significantly dependent on daylength. This daylength effect should be incorporated in a feed evaluation system.

\begin{tabular}{|c|c|c|c|c|c|c|c|}
\hline & Oct & Nov & Dec & Jan & Feb & March & P-Value \\
\hline \multicolumn{8}{|l|}{ Voluntary intake } \\
\hline \\
\hline $\mathrm{OM}$ & 59.38 & 58.28 & 59.16 & 58.45 & 58.70 & 57.44 & 0.48 \\
\hline NDF & 55.78 & 54.77 & 56.13 & 55.91 & 56.89 & 55.99 & 0.28 \\
\hline $\mathrm{CP}$ & $46.51^{\mathrm{bcd}}$ & $44.61^{\mathrm{bc}}$ & $49.33^{d}$ & $44.91 \mathrm{~cd}$ & $41.22^{\mathrm{b}}$ & $38.91^{\mathrm{a}}$ & 0.0001 \\
\hline \multicolumn{8}{|l|}{ Eating time: } \\
\hline $\mathrm{min} / \mathrm{d}$ & 301.40 & 260.26 & 263.12 & 275.30 & 292.14 & 266.25 & 0.37 \\
\hline $\mathrm{min} / \mathrm{g} \mathrm{DM} / \mathrm{kg} \mathrm{BW} 0.75$ & $6.25^{\mathrm{b}}$ & $5.39^{a b}$ & $5.63^{\circ}$ & $6.08^{\mathrm{b}}$ & $5.76^{\mathrm{b}}$ & $4.49 \mathrm{a}$ & 0.04 \\
\hline Meals (number/d) & $6.84 \mathrm{bc}$ & $6.53^{\mathrm{b}}$ & $5.44 \mathrm{a}$ & $7.96^{c}$ & $5.93^{a b}$ & $5.64^{a}$ & 0.0001 \\
\hline \multicolumn{8}{|l|}{ Rumination time: } \\
\hline $\min / d$ & 572.06 & 569.32 & 539.29 & 563.86 & 572.45 & 553.97 & 0.58 \\
\hline $\mathrm{min} / \mathrm{g} \mathrm{DM} / \mathrm{kg} \mathrm{BW} 0.75$ & $11.70^{b}$ & $11.75^{b}$ & $11.59^{\mathrm{b}}$ & $12.44^{\circ}$ & $11.58 \mathrm{~b}$ & $9.53^{a}$ & 0.02 \\
\hline
\end{tabular}

